\title{
Analisis Tingkat Kesehatan Bank Mandiri Syariah Dengan Metode Risk Profile, Good Corporate Governace, Earnings and Capital
}

\author{
Anik $^{1 *}$, Suhesti Ningsih ${ }^{2)}$ \\ ${ }^{1,2}$ Institut Teknologi Bisnis AAS Indonesia \\ *Email korespondensi: karjunia-anik@yahoo.com
}

The purpose of this research is to see the soundness level of Bank Syariah Mandiri with the method of Risk Profile, Good Corporate Governance, Earnings and Capital. The research method uses quantitative methods. Production factors in the RGEC method are the risk profile using credit risk (NPF), liquidity risk (FDR), income (ROA, ROE and BOPO) and capital (CAR). On the results of Good Corporate Governance using data processed and obtained from PT. Bank Syariah Mandiri. The object of this research is PT. Bank Syariah Mandiri. The sampling technique in this study using purposive sampling. This research period is 2013-2017. The data analysis technique used in this research is quantitative descriptive and using the RGEC method (Risk Profile, Good Corporate Governance, Earnings and Car), as for the benchmarks to determine the soundness level of a bank after each examination, namely by determining the results of the study classified into the bank's health rating. The results showed that the health of PT. Bank Syariah Mandiri which uses the Risk Profile approach, Good Corporate Governance, Earnings, and Capital as a whole can be said that Bank Syariah Mandiri is a fairly healthy bank.

Keywords: Health level; Bank Syariah Mandiri; the RGEC method

Saran sitasi: Anik, \& Ningsih, S. (2020). Analisis Tingkat Kesehatan Bank Mandiri Syariah Dengan Metode Risk Profile, Good Corporate Governace, Earnings and Capital. Jurnal Ilmiah Ekonomi Islam, 6(03), 724-730. doi:http://dx.doi.org/10.29040/jiei.v6i3.1466

DOI: http://dx.doi.org/10.29040/jiei.v6i3.1466

\section{PENDAHULUAN}

Bank yang sehat adalah bank yang menjalankan fungsi-fungsinya dengan baik. Bank tersebut mampu menjaga dan memelihara kepercayaan masyarakat, dapat menjalankan fungsi intermediasi, dapat membantu kelancaran lalu lintas pembayaran serta dapat digunakan pemerintah dalam melaksanakan berbagai kebijakannya terutama kebijakan moneter. Kesehatan suatu bank merupakan kepentingan semua pihak terkait, yaitu pemilik dan pengelola bank, masyarakat pengguna jasa bank dan Bank Indonesia selaku pembina dan pengawas. Perbankan harus selalu dinilai kesehatannya agar tetap prima dalam melayani para nasabahnya. Bank yang tidak sehat bukan hanya membahayakan perbankan itu saja akan tetapi pihak lain (Khalil \& Fuadi, 2016), (McGuire \& Tarashev, 2008).

Penilaian kesehatan dilakukan dengan menggunakan hasil dari laporan keuangan yang telah dipublikasikan oleh bank. Laporan keuangan merupakan media informasi yang bertujuan untuk memberikan informasi tentang posisi keuangan, kinerja keuangan, dan perubahan posisi keuangan pada perusahaan (Padmantyo, 2011); (Tho'in, 2019). Laporan keuangan sebagai alat komunikasi bagi pihak yang terkait dalam perusahaan (Margaretha, 2017). Pihak-pihak yang berkepentingan dalam perusahaan (stakeholder) diantaranya pimpinan perusahaan, pemegang saham, investor, kreditor, pemasok, pemerintah, karyawan (Du \& Roohani, 2007), (Palepu \& Healy, 2013).

Sejalan dengan perkembangan sektor perbankan, Bank Indonesia menyempurnakan metode penilaian kesehatan bank dengan memperbarui peraturan BI dengan yang sebelummnya PBI. NO. 6/10/PBI/2004 tentang penilaian tingkat kesehatan bank dengan menggunakan metode CAMELS (Capital, Asset quality, Management, Earnings, Liquidity and Sensitivy to Market Risk) menjadi PBI. NO.13/1/PBI/2011 tentang penilaian tingkat 
kesehatan bank dengan menggunakan pendekatan resiko (Risk-Based Bank Rating/RBBR) yang dalam penelitian ini disebut dengan RGEC (Risk Profile, Good Corporate Governance, Earnings and Capital).

Dengan dilakukannya penilaian menggunakan metode RGEC ini, bank syariah dapat melakukan evaluasi dan perbaikan jika ditemukan kelemahan dalam mengambil keputusan strategi pada bank syariah. Dengan begitu bank syariah dapat bersaing dengan bank konvensional dan bank syariah lainnya dalam meningkatkan mutu kesehatan bank. Selain itu, para investor dapat mengetahui posisi bank yang diberikan modal dalam keadaan baik atau buruk dan para calon investor dapat lebih selektif dalam memberikan modal para bank syariah mana yang kiranya akan memberikan keuntungan yang lebih besar dilihat dari posiisi kesehatan perusahaan tersebut.

Bank Syariah Mandiri merupakan salah satu bank yang berkembang pesat di tengah persaiangan antar bank dan lembaga keuangan yang ada di Indonesia. PT Bank Syariah Mandiri mulai beroperasi pada tahun 1999 hingga saat ini telah memiliki jaringan operasional 737 kantor layanan di Indonesia dan akses lebih dari 196000 jaringan ATM, sehingga diperlukannya penilaian terhadap laporan keuangan agar PT. Bank Syariah Mandiri dapat mengetahui tingkat kesehatan bank. Metode RGEC dapat digunakan untuk mengetahui tingkat kesehatan PT. Bank syariah mandiri.

Kesehatan bank merupakan gambaran kondisi keuangan, pengelolaan dan kegiatan operasional perbankan (Tho'in \& Irawati, 2018). Menurut Damayanti dan Chaniago (2015), kesehatan suatu bank dapat diartikan sebagai kemampuan bank untuk hasil dari pelaksanaan kegiatan-kegiatan operasional perbankan dan mampu memenuhi semua kewajibannya dalam melaksanakan tugas sesuai dengan peraturan perbankan. Menurut UU No. 10 tahun 1998 tentang Perbankan, bank wajib memelihara tingkat kesehatan bank sesuai dengan ketentuan kecukupan modal, kualitas aset, kualitas manajemen, likuiditas, rentabilitas, solvabilitas dan aspek lain yang berhubungan dengan usaha bank dan wajib melakukan kegiatan usaha sesuai dengan prinsip kehati-hatian. Dalam pengertian lain tingkat kesehatan bank merupakan hasil penelitian kualitatif atas berbagai aspek yang berpengaruh terhadap kondisi atau kinerja suatu bank melalui penilaian faktor permodalan, kualitas asset, manajemen, rentabilitas, liquiditas (Nuryanto dkk, 2014); (Santosa, Tho'in, \& Sumadi, 2020). Penilaian terhadap faktor-faktor tersebut dilakukan melalui penilian kualitatif setelah mempertimbangkan pengaruh dari faktor lainnya seperti kondisi industry perbankan dan perekonomian nasional (Muchdarsyah, 2000), (Bhutta, 2014). Untuk dapat menjalankan fungsinya dengan baik, bank harus mempunyai modal yang cukup, menjaga kualitas asetnya dengan baik, dikelola dengan baik dan dioperasikan berdasarkan prinsip kehati-hatian, menghasilkan keuntungan yang cukup untuk mempertahankan kelangsungan usahanya, serta memelihara likuiditasnya sehingga dapat memenuhi kewajibannya setiap saat (Syariati, 2012).

Tingkat kesehatan bank diukur melalui peringkat komposit yang diatur dalam PBI 13/1/PBI/2011 Tentang kesehatan Bank. Peringkat komposit Tingkat kesehatan Bank ditetapkan berdasarkan Analisis secara komprehensif dan terstruktur terhadap peringkat tiap tiap faktor yang disebutkan sebelumnya. Pada risiko kredit, risiko ini muncul karena kegagalan nasabah atau pihak lain dalam memenuhi liabilitas kepada bank islam sesuai kontrak. risiko ini disebut juga risiko gagal bayar, risiko pembiayaan, risiko penurunan rating, dan risiko penyelesaian. Risiko ini timbul akibat terkontrasinya penyaluran dana kepada satu pihak atau kelompok pihak, industri sektor, dan/atau area geografis tertentu yang berpotensi menimbulkan kerugian yang cukup besar dan dapat mengancam kelangsungan bisnis syariah tersebut (Wahyudi, dkk., 2013). Dalam PBI Nomor 13/1/PBI/2011 tentang penilaian tingkat kesehatan bank umum untuk mengukur kredit dapat diketahui dengan mengukur proporsi pembiayaan menggunakan rasio NPF (Non Performing Financing) dan kredit kualitas rendah dengan total pembiayaan matriks dalam pengukuran NPF adalah sebagai berikut:

Tabel 1

Matriks Pengukuran NPF

\begin{tabular}{|c|c|c|}
\hline Peringkat & Keterangan & Kriteria \\
\hline 1 & PK-1 & $<2 \%$ \\
\hline 2 & PK-2 & $2 \%-<5 \%$ \\
\hline 3 & PK-3 & $5 \%<8 \%$ \\
\hline 4 & PK-4 & $8 \%-<12 \%$ \\
\hline 5 & PK-5 & $\geq 12 \%$ \\
\hline
\end{tabular}

Tabel matriks pengukuran NPF diatas menjelaskan tentang pengukuran kesehatan bank dengan rasio NPF bank. Jika tingkat NPF kurang dari 
$2 \%$ maka bank dalam keadaan sangat sehat (PK-1). $N P F$ bank antara $2 \%$ sampai dengan kurang dari $5 \%$ bank dalam keadaan sehat (PK-2). NPF bank pada posisi $5 \%$ sampai dengan kurang dari $8 \%$ maka dalam keadaan cukup sehat (PK-3). Jika NPF bank dalam posisi kurang $8 \%$ sampai kurang dari $12 \%$ maka keadaan bank kurang sehat (PK-4). Sedangkan jika NPF lebih dari $12 \%$ maka bank dalam keadaan tidak sehat (PK-5).

Pada resiko likuiditas, resiko ini terjadi akibat ketidak mampuan bank syariah dalam memenuhi likuiditas yang jatuh tempo. Untuk memenuhi likuiditasnya, bank dapat menggunakan pendanaan sumber kas dan asset likuid berkualitas tinggi yang dapat digunakan tanpa menggangu aktivitas dan kondisi keuangan bank. Risiko ini muncul sebagai kansekuensilogis dan ketidaksamaan waktu jatuh tempo antara sumber pendanaan bank, yakni DPK (Dana Pihak Ketiga) dan akad pembiayaan bank kepada debitur (Wahyudi, dkk., 2013). Dalam PBI. No 13/1/PBI/2011 tentang penilaian kesehatan bank umum untuk mengukur risiko likuiditas dapat diketahui dengan menggunakan rasio FDR (Financing Deposit Ratio). Matriks dalam pengukuran FDR adaalah sebagai berikut:

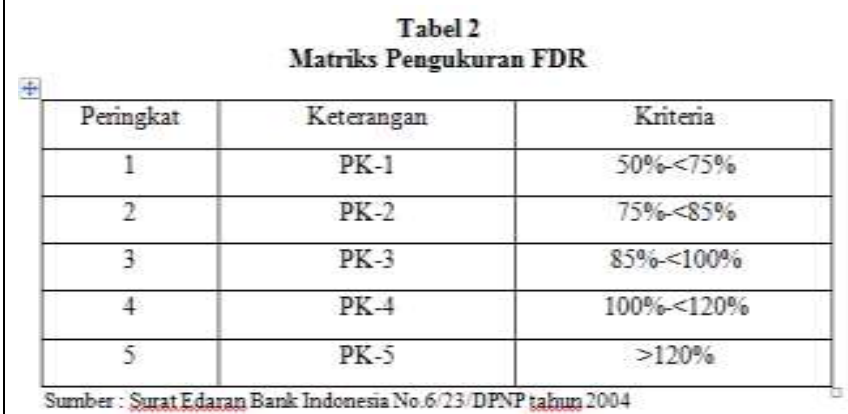

Tabel matriks pengukuran FDR di atas menjelaskan tentang pengukuran Tingkat kesehatan Bank dengan melihat dari rasio FDR bank.Di jelaskan Bahwa jika FDR berada diantara 50\% sampai kurang dari 75\% maka bank Dalam keadaan sangat sehat (PK1). FDR antara $75 \%$ sampai dengan kurang Dari $85 \%$ maka bank dalam keadaan sehat (PK-2). jika FDR bank antara $85 \%$ Sampai dengan kurang dari $100 \%$ maka bank dalam posisi cukup sehat (PK-3) FDR bank antara $100 \%$ sampai dengan kurang dari $120 \%$ bank dalam keadaan kurang sehat (PK-4). Sedangkan jika FDR bank lebih dari $120 \%$ maka bank dapat dikatakan tidak sehat (PK-5).

Good corporate governance menurut Bank Dunia (World Bank) adalah sebagai kumpulan hukum, peraturan, dan kaidah-kaidah yang wajib dipenuhi, yang dapat mendorong sumber-sumber perusahaan untuk berfungsi secara efisien guna menghasilkan nilai ekonomi jangka panjang yang berkesinambungan bagi para pemegang saham maupun masyarakat sekitar secara keseluruhan (Effendi, 2009). Good Corporate Governance (GCG) adalah mekanisme penting yang diharapkan dapat mendorong praktik bisnis yang sehat. Penilaian faktor good corporate governance (GCG) merupakan penilaian terhadap kualitas manajemen bank atas pelaksanaan prinsip-prinsip GCG (Mulazid, 2016).

Rentabilitas adalah kemampuan perusahaan untuk memperoleh hasil bersih (laba) dengan modal yang digunakannya. Rentabilitas dapat dihitung dengan membandingkan laba usaha dengan jumlah modalnya (Gilarso: 2008). Penilaian faktor rentabilitas bertujuan untuk mengetahui kemampuan perusahan dalam menghasilkan laba. Faktor rentabilitas ini meliputi evaluasi terhadap kinerja rentabilitas, sumber-sumber rentabilitas, kesinambungan rentabilitas dan manajemen rentabilitas. Tujuan penilaian rentabilitas adalah untuk mengevaluasi kemampuan Rentabilitas bank untuk mendukung kegiatan operasional dan permodalan bank (Athanasoglou, et.al, 2008). Dalam PBI No 13/1/PBI/2011 Tentang penilaian kesehatan bank umum untuk mengukur Rentabilitas dapat menggunakan Rasio ROA (Return On Asset), ROE (Return On Equity) dan BOPO (Beban Operasional terhadap Pendapatan)

Tabel 3

Matriks Pengukuran ROA

\begin{tabular}{|c|c|c|}
\hline Peringkat & Keterangan & Criteria \\
\hline 1 & PK-1 & $>1,45 \%$ \\
\hline 2 & PK-2 & $1,25 \%-1,45 \%$ \\
\hline 3 & PK-3 & $0,99 \%-1,25 \%$ \\
\hline 4 & PK-4 & $0,765 \%-0,99 \%$ \\
\hline 5 & PK-5 & $<0,765 \%$ \\
\hline
\end{tabular}

Sumbex: (Lampiran SK DIR BI No 30/12/KEP/DIR)

Tabel 4

Matriks Pengukuran ROE

\begin{tabular}{|c|c|l|}
\hline Peringkat & Keterangan & \multicolumn{1}{|c|}{ Kriteria } \\
\hline 1 & PK-1 & Perolehan laba sangat sehat (rasio diatas 20\%) \\
\hline 2 & PK-2 & $\begin{array}{l}\text { Perolehan laba tinggi (rasio ROE berkisax } \\
\text { antaxa 12.51\% sampai dengan 20\%) }\end{array}$ \\
\hline 3 & PK-3 & $\begin{array}{l}\text { Perolehan 1aba cukup tinggi (rasio ROE } \\
\text { berkisar antara 5,01\% sampai dengan 12,5\%) }\end{array}$ \\
\hline 4 & PK-4 & $\begin{array}{l}\text { Perolehan laba rendah atau cenderung } \\
\text { mengalami kerugian (ROE mengarah negative } \\
\text { rasio berkisar antara 0\% sampai dengan 5\%) }\end{array}$ \\
\hline 5 & PK-5 & $\begin{array}{l}\text { Bank mengalami kerugian yang besar (ROE } \\
\text { negativerasio dibawah 0\%) }\end{array}$ \\
\hline Sumber: (Surat Edaran Bank Sumut No 056/DIR/DPP-PC/SE/04)
\end{tabular}


Tabel s

Matriks Kriteria Penetapan Peringicat Komponen Rentabilitas (BOPO)

\begin{tabular}{|c|c|l|}
\hline Peringkat & Keterangan & \multicolumn{1}{|c|}{ Criteria } \\
\hline 1 & PK-1 & $\begin{array}{l}\text { Tingkat etisiensi sangat schat (rasio } \\
\text { BOPO kurang dari 83\%) }\end{array}$ \\
\hline 2 & PK-2 & $\begin{array}{l}\text { Tingkat efisiensi sehat (rasio BOPO } \\
\text { berkisar antara 83\% sampai dengan 85\%) }\end{array}$ \\
\hline 3 & PK-3 & $\begin{array}{l}\text { Tingkat efisiensi cukup sehat (rasio } \\
\text { BOPO berkisar antara 83\% sampal } \\
\text { dengan 87\%) }\end{array}$ \\
\hline 4 & PK-4 & $\begin{array}{l}\text { Tingkat efisiensi kurang sehat (rasio } \\
\text { BOPO berkisar antara 87\% sampai } \\
\text { dengan 89\%) }\end{array}$ \\
\hline 5 & PK-5 & $\begin{array}{l}\text { Tingkat efisiensi tidak sehat (rasie diatas } \\
89 \%)\end{array}$ \\
\hline
\end{tabular}

Penilaian atas faktor permodalan meliputi evaluasi terhadap kecukupan permodalan dan kecukupan pengelolaan permodalan. Dalam melakukan perhitungan permodalan, bank wajib mengikuti ketentuan bank Indonesia yang mengatur mengenai kewajiban penyediaan modal minmum. Bank juga harus memenuhi rasio kecukupan modal yang disediakan untuk mengantisipasi risiko (Athanasoglou, et.al, 2008). Untuk mengukur pada permodalan adalah dengan menggunakan rasio CAR (Capital Adequacy Ratio). Matriks yang digunakan dalam pengukuran CAR adalah sebagai berikut:

Tabel 6

Matriks Pengukuran CAR

\begin{tabular}{|c|c|c|}
\hline Peringkat & Keterangan & Kriteria \\
\hline 1 & PK-1 & CAR $>12 \%$ \\
\hline 2 & PK-2 $\%$ & $9 \%$ CAR $<12 \%$ \\
\hline 3 & PK-3 & $8 \% \leq \mathrm{CAR}<9 \%$ \\
\hline 4 & PK-4 & $6 \% \leq \mathrm{CAR}<8 \%$ \\
\hline 5 & PK-5 & CAR $\leq 6 \%$ \\
\hline
\end{tabular}

Sumber : Surat Edaran Bank Indonesia No.13/24/DPNP tahun 2011

Tabel matriks pengukuran CAR di atas menjelaskan tentang pengukuran tingkat kesehatan bank dengan melihat dari rasio CAR bank. Bank dikatakan sangat sehat (PK-1) jika CAR lebih dari 12\%. Jika CAR diantara 9\% sampai dengan dari 12\% maka bank dalam keadaan sehat (PK-2). Jika CAR antara $8 \%$ sampai dengan kurang dari $9 \%$ maka bank dalam keadaan cukup sehat (PK-3). CAR bank dalam posisi kurang sehat (PK-4) jika CAR antara 6\% sampai dengan kurang dari $8 \%$. Sedangkan bank dikatakan tidak sehat (PK-5) jika CAR kurang dari $6 \%$.

\section{METODOLOGI PENELITIAN}

Penelitian ini dengan menggunakan jenis penelitian deskriptif kuantitatif yang menggunakan metode RGEC yang terdiri dari risk profile, good corporate governance, earnings dan capital. Sumber data dalam penelitian ini adalah data sekunder berupa laporan keuangan Bank Syariah Mandiri (BSM) tahun 2013-2017 di website resmi bank syariah mandiri yaitu http://www.syariahmandiri.co.id yang didukung dengan jurnal dan buku referensi yang berkaitan dengan penelitian, maupun informasi-informasi lain yang berkaitan dengan penelitian ini.

Populasi pada penelitian ini adalah seluruh bank umum syariah yang berjumlah 12 bank. Teknik pengambilan sampel menggunakan teknik purposive sampling. Sampel adalah sebagian dari jumlah dan karakteristik yang dimiliki oleh populasi (Emilia, 2017). Teknik pengambilan sampel dilakukan dengan Purpose Sampling, yaitu teknik penentuan sampel dengan pertimbangan tertentu. Teknik ini bertujuan untuk mendapatkan sampel yang sesuai dengan kebutuhan penelitian. kriteria sampel yang ditetapkan pada penelitian ini, antara lain:

a. Bank umum syariah yang terdaftar di Bank Indonesia.

b. Bank umum syariah yang menerbitkan laporan keuangan secara publis selama tahun 2013-2017.

c. Bank umum syariah yang menerbitkan laporan tata kelola secara publis selama tahun 2013-2017.

d. Bank umum syariah yang mampu memadukan idealisme usaha dengan nilai-nilai rohani, yang melandasi kegiatan operasionalnya dengan kantor cabang terbanyak.

Dari kriteria diatas diperoleh sampel penelitian ini ialah PT. Bank Syariah Mandiri.

Teknik analisis data yang digunakan adalah analisis keuangan dengan menggunakan metode RGEC. Data yang diperoleh pada penelitian ini dianalisa secara deskriptif. Data yang diperoleh kemudian diolah dengan rumus yang sesuai pada definisi operasional variabel. Langkah-langkah yang digunakan untuk menilai tingkat kesehatan bank untuk masing-masing faktor dan komponennya adalah sebagai berikut:

Mengumpulkan data-data dari laporan keuangan perusahaan berkaitan dengan variabel penelitian.

Melakukan pemeringkatan masing-masing analisis NPF, FDR, GCG, ROA, ROE, BOPO dan CAR. 
Menetapkan peringkat komposit penilaian tingkat kesehatan bank dari tahun 2013 hingga tahun 2017. Nilai komposit untuk rasio keuangan masingmasing komponen yang menempati peringkat komposit akan bernilai sebagai berikut :

a. Peringkat $1=$ setiap kali ceklist dikalikan dengan 5

b. Peringkat $2=$ setiap kali ceklist dikalikan dengan 4

c. Peringkat $3=$ setiap kali ceklist dikalikan dengan 3

d. Peringkat $4=$ setiap kali ceklist dikalikan dengan 2

e. Peringkat $5=$ setiap kali ceklist dikalikan dengan 1

Nilai komposit yang telah diperoleh dari mengalikan tiap ceklist kemudian ditentukan bobotnya dengan mempersentasikan. Adapun bobot/ persentase untuk menentukan peringkat komposit keseluruhan komponen sebagai berikut:

\section{Tabel 7}

Bobot Penetapan Peringkat Komposit

\begin{tabular}{|c|c|c|}
\hline Bobot $\%$ & Peringkat komposit & Keterangan \\
\hline $86-100$ & PK 1 & Sangat sehat \\
\hline $71-85$ & PK 2 & Sehat \\
\hline $61-70$ & PK 3 & Cukup sehat \\
\hline $41-60$ & PK 4 & Kurang sehat \\
\hline$<40$ & PK 5 & Tidak sehat \\
\hline
\end{tabular}

Sumber : Emilia, (2014)

Peringkat komposit $=\frac{\text { Jumlah Nilai Komposit }}{\text { Total Nilai Komposit Keseluruhan }} \times 100 \%$

Sumber : Emilia, (2014)

Menarik kesimpulan terhadap tingkat kesehatan bank sesuai dengan standar perhitungan kesehatan bank yang telah ditentukan oleh bank Indonesia berdasarkan perhitungan analisis rasio tersebut.

\section{HASIL PENELITIAN DAN PEMBAHASAN}

3.1 Profil Risiko atau Risk Profile memperoleh predikat cukup sehat dan sehat tercermin dengan perhitungan Financing to Deposit Ratio (FDR) dan Non Performing Financing (NPF) sebagai berikut:

a. Pada tahun 2013 PT. Bank Syariah Mandiri memperoleh FDR (Financing to Deposit Ratio ) sebesar 89,37\% yang berarti setiap dana yang dihimpun bank dapat mendukung pinjaman yang diberikan sebesar $89,37 \%$ dari total pembiayaan yang yang diberikan, dalam hal ini bank dapat mengelola simpanan dalam bentuk pembiayaan sebesar $89,37 \%$. Sehingga kemampuan menghasilkan laba suatu bank akan meningkat seiring peningkatan pemberian kredit atau pembiayaan. Sesuai dengan matriks penetapan nilai komposit yang ada di Surat Edaran Bank Indonesia memiliki FDR sebesar 89,37\% dengan tingkat komposit 3 dan predikat cukup sehat karena melebihi $85 \%$ dan kurang dengan 100\%. Dalam hal ini menunjukan PT. Bank Syariah Mandiri mampu menjalankan kegiatan operasionalnya dan dalam keadaan tidak liquid. Semakin tinggi persentase FDR maka semakin baik yang menunjukan bahwa PT. Bank Syariah Mandiri meminjamkan seluruh dananya atau tidak liquid, dan sebaliknya semakin kecil persentase FDR maka menunjukan bahwa PT. Bank Syariah Mandiri adalah bank yang liquid.

b. Sedangkan pada tahun 2013 diperoleh NPF (Non Performing Financing) sebesar $2,28 \%$ berarti terdapat $2,28 \%$ dana yang termasuk dalam pembiayaan kurang lancar, diragukan dan macet dari total pembiayaan yang diberikan oleh bank. Semakin besar NPF menunjukan jika bank kurang baik dalam menyeleksi calon peminjam. Dan sesuai dengan matriks penetapan nilai komposit yang ada di Surat Edaran Bank Indonesia Memiliki NPF sebesar 2,28\% dan termasuk dalam peringkat sehat karena melebihi batas maksimal $2 \%$.

Risk profil dapat mententukan tingkat kesehatan bank pada PT Bank Syariah Mandiri pada periode tahun 2013 dengan cara memperkecil komponen Risk profil yaitu rasio FDR pada angka $50 \%$ sampai dengan $75 \%$ dan memperkecil rasio NPF tidak melebihi $2 \%$ maka tingkat kesehatan bank dari predikat cukup sehat dan sehat menjadi sangat sehat.

3.2 Good Corporate governance, pada tahun 2013 PT. Bank Syariah Mandiri memperoleh predikat sehat berdasarkan hasil self assessment PT. Bank Syariah Mandiri yang diperoleh dari laporan tata kelola perusahaan. Hal ini membuktikan bahwa pada tahun 2013 PT. Bank Syariah Mandiri melakukan manajemen yang baik dan mengikuti 
prinsip-prinsip GCG sesuai dengan ketentuan yang sudah ditetapkan oleh Peraturan Bank Indonesia. Good Corporate governance dapat menentukan tingkat kesehatan bank pada PT Bank Syariah Mandiri dengan cara terus meningkatkan manajemen yang baik dan mengikuti prinsip-prinsip GCG berdasarkan PBI No. 13/1/PBI/2011 sehingga dari predikat sehat bisa memperoleh predikat sangat sehat.

3.3 Rentabilitas atau Earnings memperoleh predikat Sehat yang tercermin dari perhitungan rasio keuangan yang digunakan baik itu ROA, ROE, dan BOPO sebagai berikut:

a. Pada tahun 2013 diperoleh ROA (Return On Asset) sebesar $1,52 \%$ berarti tingkat produktivitas asset dari rata rata total asset yang digunakan menghasilkan laba sebesar $1,52 \%$. Semakin tinggi persentase maka tingkat produktivitas akan semakin meningkat. Dan sesuai dengan matriks penetapan nilai komposit yang ada di Surat Edaran Bank Indonesia Memiliki ROA sebesar $1,52 \%$ dan predikat sangat sehat atau tingkat komposit 1 karena lebih besar dari $1,45 \%$.

b. Pada tahun 2013 PT. Bank Syariah Mandiri memperoleh ROE (Return On Equity) sebesar $44,58 \%$, berarti terdapat $44,58 \%$ laba bersih yang diperoleh dari modal sendiri yang ditanamkan di bank. Semakin besar persentase ROE maka semakin besar kenaikan laba bersih yang diperoleh oleh bank, dan sebaliknya semakin kecil persentase ROE maka semakin kecil laba bersih yang diterima oleh bank. Dan sesuai dengan matriks penetapan nilai komposit yang ada di Surat Edaran Bank Indonesia Memiliki ROE sebesar $44,58 \%$ dengan predikat sangat sehat karena rasio diatas $20 \%$.

c. Pada tahun 2013 PT. Bank Syariah Mandiri memperoleh BOPO sebesar 84,02\%, berarti terdapat $84,02 \%$ biaya operasional yang digunakan untuk kegiatan operasional bank. Semakin kecil persentase BOPO maka semakin efisien biaya operasional yang dikeluarkan bank dan sebaliknya semakin besar persentase BOPO maka menunjukan kurangnya kemampuan bank dalam menekan biaya operasional dan dapat menimbulkan kerugian bank. Dan sesuai dengan matriks penetapan nilai komposit yang ada di Surat Edaran Bank Indonesia memilki BOPO sebesar dengan $87 \%$ berada pada predikat cukup sehat Karena rasio masih berkisar antara $85 \%$ sampai dengan $87 \%$.

Rentabilitas atau Earnings dapat menentukan tingkat kesehatan bank pada PT Bank Syariah Mandiri dengan cara meningkatkan komponen Earnings yaitu ROA > 1,45\% dan ROE > 20\% serta menurunkan rasio BOPO < $83 \%$ sehingga dari predikat sangat sehat, sangat sehat dan cukup sehat menjadi predikat sangat sehat semuanya.

3.4 Permodalan atau Capital memperoleh predikat Sangat Sehat tercermin dari perhitungan rasio CAR dimana pada tahun 2013 diperoleh CAR (Capital Adequacy Ratio) PT. Bank Syariah Mandiri sebesar $14,10 \%$, dalam arti seluruh permodalan yang dimiliki bank tersebut dapat mengantisipasi kemungkinan risiko kredit sebesar $14,10 \%$. Dan sesuai dengan matriks penetapan nilai komposit yang ada di Surat Edaran Bank Indonesia memiliki CAR sebesar $14,10 \%$ berada pada predikat sangat sehat atau tingkat komposit 1 karena melebihi batas minimal yaitu $12 \%$. Capital dapat menentukan tingkat kesehatan bank pada PT Bank Syariah Mandiri dengan cara mempertahankan komponen capital yaitu CAR > 12\% sehingga tingkat kesehatan Bank stabil sangat sehat.

Dapat disimpulkan bahwa pada tahun 2013 PT.

Bank Syariah Mandiri selama tahun 2013 memperoleh peringkat komposit akhir 2 dengan kategori SEHAT sebab dari perhitungan nilai komposit akhir diperoleh nilai sebesar $82,86 \%$ atau $71 \% \leq \mathrm{PK}<85 \%$ yang artinya bank tersebut dikategorikan sehat. Tingkat kesehatan PT Bank Syariah Mandiri dapat meningkat dari predikat sehat menjadi sangat sehat dengan meningkatkan komponen risk profile, good corporate government, earnings dan capital.

\section{KESIMPULAN}

Berdasarkan pembahasan di atas, maka dapat disimpulkan bahwa penilaian kesehatan PT. Bank Syariah Mandiri yang diukur menggunakan pendekatan Risk Profile, Good Corporate Governance, Earnings dan Capital secara keseluruhan dapat dikatakan bahwa Bank Syariah Mandiri merupakan bank yang cukup sehat. 


\section{UCAPAN TERIMA KASIH}

Kami ucapkan banyak terima kasih kepada pemerintah melalui RISTEKBRIN yang telah memberikan dukungan pendanaan penuh dalam penelitian ini, sehingga penelitian ini dapat selesai tepat pada waktunya.

\section{REFERENSI}

Bhutta, N. (2014). Payday loans and consumer financial health. Journal of Banking \& Finance, 47, 230-242.

Athanasoglou, P. P., Brissimis, S. N., \& Delis, M. D. (2008). Bank-specific, industry-specific and macroeconomic determinants of bank profitability. Journal of international financial Markets, Institutions and Money, 18(2), 121-136.

Damayanti, D. D., \& Chaniago, H. (2015). Pengaruh risiko usaha dan good corporate governance terhadap skor kesehatan bank pada bank umum swasta nasional devisa. Journal of Business \& Banking (JBB), 4(2), 217-230.

Du, H., \& Roohani, S. (2007). Meeting challenges and expectations of continuous auditing in the context of independent audits of financial statements. International Journal of Auditing, 11(2), 133-146.

Effendi, M. A. (2009). The power of good corporate governance: teori dan implementasi. Jakarta: Salemba Empat.

Gilarso, T. (2008). Pengantar Ilmu Ekonomi Mikro, Edisi 5. Yogyakarta: Kanisius.

Khalil, M., \& Fuadi, R. (2016). Analisis Penggunaan Metode Risk Profile, Good Corporate Governance, Earning, and Capital (Rgec) Dalam Mengukur Kesehatan Bank Pada Bank Umum Syariah Di Indonesia Periode 2012-2014. Jurnal Ilmiah Mahasiswa Ekonomi Akuntansi, 1(1), 2035.

Margaretha, F. (2017). Faktor-faktor Yang Mempengaruhi Kinerja Keuangan Perbankan Di Indonesia. Jurnal Manajemen, 6(2).

McGuire, P., \& Tarashev, N. A. (2008). Bank health and lending to emerging markets. BIS Quarterly Review, December.

Muchdarsyah, S. (2000). Manajemen Dana Bank. Bumi Aksara, Jakarta.

Mulazid, A. S. (2016). Pelaksanaan Sharia Compliance Pada Bank Syariah (Studi Kasus Pada Bank Syariah Mandiri, Jakarta). Madania: Jurnal Kajian Keislaman, 20(1), 37-54.
Nuryanto, R., Tho'in, M., \& Wardani, H. K. (2014). Rasio Likuiditas, Rasio Solvabilitas, Rasio Rentabilitas Koperasi Jasa Keuangan Syariah Di Jawa Tengah. Jurnal Akuntansi dan Pajak, 15(01).

Padmantyo, S. (2011). Analisis Manajemen Laba Pada Laporan Keuangan Perbankan Syariah (Studi Pada Bank Syariah Mandiri Dan Bank Muamalat Indonesia). Benefit: Jurnal Manajemen dan Bisnis.

Palepu, K \& Healy, P (2013). Business analysis and valuation: Using financial statements, text and cases.

Santosa, S., Tho'in, M., \& Sumadi, S. (2020). Analisis Tingkat Kesehatan Bank Syariah Menggunakan Rasio Permodalan, Profitabilitas, Pembiayaan, dan Risiko Kredit. Jurnal Ilmiah Ekonomi Islam, 6(2), 367-371.

Siyamto, Y., \& Sumadi, S. (2018). Kinerja Keuangan Bank Umum Syariah Di Indonesia Dengan Pendekatan Metode Market Value Added (MVA). Jurnal Ilmiah Ekonomi Islam,4(03), 206-212.

Susanto, H., AR, M. D., \& Zahroh, Z. A. (2016). Analisis Tingkat Kesehatan Bank Dengan Menggunakan Metode Rgec (Risk Profile, Good Corporate Governance, Earning, Capital)(Studi Pada PT Bank Mandiri. Yang Terdaftar Di Bei Tahun 2010-2014). Jurnal Administrasi Bisnis, 35(2), 60-67.

Syariati, A. (2012). The Effect Of Islamic Comercial Banks' health And Their Cost Of Fund Upon Its Financing In Indonesia Over 20052009. Proceeding of International Conferrence of AIMI Indonesia.

Tho'in, M., Irawati, T., \& Lee, M. (2018). Risk and Financial Health Level of Shariabanking. Journal Research and Analysis: Economy, 1(1), 19-26.

Tho'in, M. (2019). The Comparison of Islamic Banking Financial Performance In Indonesia. International Journal of Scientific Research And Education, 7(5).

Wahyudi, I., Dewi, M. K., Rosmanita, F., Prasetyo, M. B., Putri, N. I. S., \& Haidir, B. M. (2013). Manajemen Risiko Bank Islam. Jakarta: Salemba Empat. 